\title{
AdVANCED CONCEPTS INTEGRATION FOR THE COMPRESSION OF CONSTRUCTION PROJECT SCHEDULE
}

\author{
SHEVTSHENKO, E.; ZAHHAROV, R.; KARAUlOVA, T. \& WANG, Y.
}

Abstract: This paper considers the set of advanced approaches that are successfully applied in industrialized off-site production of modular manufacturing facilities for pharmaceutical and biotech industries.

The main advantages are as follows: reduction of stock-out situations and decrease in stock value, reduction of administration time for material coordination and substantial decrease in manufacturing lead time with concurrent increase of production capacity. From customer perspective this means faster time to market, due to earlier completion of pharmaceutical facility. Current paper shows and proves that integration of different approaches for construction industry realizes in huge changes in efficiency of construction industry. The lean manufacturing, modular construction concept and integration of informational systems enable to achieve global success.

Key words: ERP, MRP, CAD, modular manufacturing, BOM
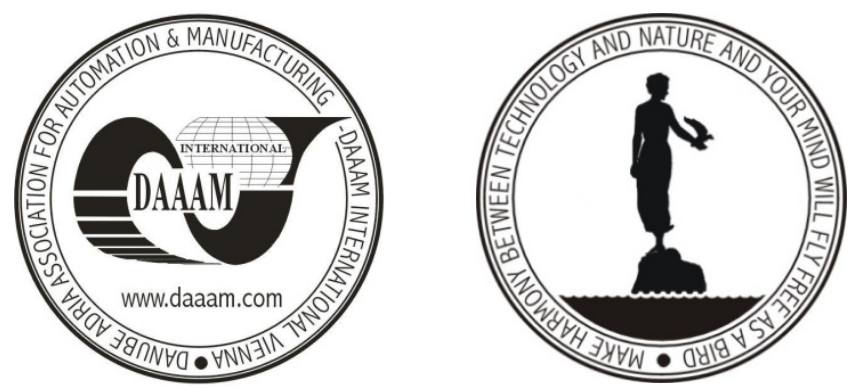

Authors' data: Dr. Shevtshenko, E[duard]*; B. Sc. Eng. Zahharov, R[oman]**; Dr. Karaulova, T[atjana]*; Dr. Wang, Y[an]***, *Tallinn University of Technology, Ehitajate tee 5, 19086, Tallinn, EE, ** Tallinn University of Technology, Uusmaa str 1/3, 75312, Tallinn, EE, ***University of Central Florida, 4000 Central Florida Blvd., 32816-2993, Orlando, US, eduard.shevtshenko@ttu.ee, roman.zahharov@mail.ee, tatjana.karaulova@ttu.ee,wangyan@mail.ucf.edu

This Publication has to be referred as: Shevtshenko, E[duard]; Zahharov, R[oman]; Karaulova, T[atjana] \& Wang, Y[an] (2008). Advanced Concepts Integration for the Compression of Construction Project Schedule, Chapter 61 in DAAAM International Scientific Book 2008, pp. 759-772, B. Katalinic (Ed.), Published by DAAAM International, ISBN 978-3-901509-66-7, ISSN 1726-9687, Vienna, Austria

DOI: $10.2507 /$ daaam.scibook.2008.61 